\title{
RESTOCKING THE BRITISH WORLD: EMPIRE MIGRATION AND ANGLO-CANADIAN RELATIONS, 1919-30*
}

Canada is a land flowing with milk and honey for all men and women able and willing to work. People from these [British Isles] are sure of a warm reception and a happy home. Sir Wilfrid Laurier's prophesy that the twentieth century belongs to Canada will be fulfilled.

Peter Larkin, Canadian High Commissioner in London ${ }^{1}$

Throughout the 1920s Canadian politicians, immigration officials, eugenicists, educationalists, and political commentators talked about the need to 'Canadianize' all immigrants who arrived in the dominion, including those from the 'mother country'. However, this did not mean that Ottawa was out to 'de-Britannicize' those arriving from the United Kingdom. British migrants, a crucial component that underpinned Canada's cultural identity at this time, were given preferred status because their common heritage and shared cultural values mirrored those of most Anglo-Canadians. Indeed, 'Britishness' made up the bedrock of Anglo-Canadian 'national' identity. Therefore, at one level British migrants were seen as less problematic and easier to acculturate to the Canadian way of life because for many Canadians being British and Canadian were one and the same. As Alan Sears has argued, the crux of the problem in "forging a "national people" [hinged on] defining some people as more naturally Canadian (or capable of becoming Canadian) than others'. ${ }^{2}$ However, the development of a 'national people' was not an attempt by Canada to break the bonds 
of empire. Carl Berger reminded us long ago far from being incompatible the development of Canadian nationalism was premised upon it being nurtured within an imperial framework. ${ }^{3}$ Put another way, the 'highest level of citizenship', according to Barbara Roberts, 'was based on love and loyalty to Canada and to the British Empire; the two were inseparable'.

Assimilation was another matter. Although this term was also used when discussing the incorporation of British migrants into Canadian society, this process was primarily directed at the believed to be flood waves of central and eastern European immigrants with their unpronounceable names, strange languages, and alien customs. Ironically, it was this latter group which adapted more quickly to the realities of farming in Canada's western prairies or had greater forbearance to withstand the isolation when exploiting the natural wealth in the extensive forests and scattered mining communities of Canada's north. British migrants, increasingly from the sprawling urban and industrial black spots of Britain, may have possessed the cultural pedigree required by Canadians, but they often lacked the requisite skills and stamina necessary to develop Canada's primary resource sector. Instead, they quickly drifted to larger towns and cities competing for jobs in the tertiary and industrial sectors of Canada's burgeoning economy. This was where many British migrants, even before 1918, had made a noticeable and positive contribution to the economic growth of Canada - in the foundries and factories, not the farms or forests. This contradiction between the rhetoric of reinforcing a culturally homogenous society rooted in the institutions of an Anglo-Saxon heritage fell far short of the realities which occurred in the interwar period as the percentage of British migration to Canada fell steadily in the face of increasing numbers of non-British migrants who arrived on 
its shores.

The tensions which existed between the competing notions of what it was to be 'British', 'Canadian' - or, as John Darwin has posited, the formation of a 'Britannic' identity and nationalism ${ }^{5}$ - reverberated throughout the increasingly strained relations between Britain and Canada over certain aspects of overseas settlement policy. This, in turn, led to conflict rather than cooperation between London and Ottawa during the interwar period. Indeed, these anxieties reflected the changing nature of the imperial connection best exemplified by the Balfour Report (1926), which gave the dominions equal and autonomous status with the 'mother country' in a newly emerging multi-centred British Commonwealth. For many historians on both sides of the North Atlantic the political and constitutional developments which led Canada to full nationhood, enshrined as they were in the Statute of Westminster (1931), are well-known. ${ }^{6}$ The competing 'national' and 'imperial' interests that intensified during the formulation and implementation of assisted migration and empire settlement between 1919 and 1939 are also a familiar theme. Nonetheless, scholars are less familiar with how this competition fostered acute diplomatic discord between the two nations, especially in the 1920s, that by the end of the decade demonstrated that Britain was not able to impose upon the 'senior dominion' its 'imperial' agenda relating to emigration. Contrastingly, from the perspective of leading Canadian officials, in spite of sustained pressure from internal and external sources, economics could (and often did) trump ethnicity. It is these competing notions of 'Britishness' which makes empire migration so distinctive in the chronicles of Anglo-Canadian relations during this period.

For too long the 'nationalist' shackles, which have often handcuffed those in 
pursuit of a more fully integrated history of empire, are slowly being loosened. So, too, are those overly metropolitan-centric ideas that over the years have been equally constraining. Spawned, in part, by the criticisms engendered of a new generation of transnational historians dissatisfied with the traditional metropolitan-periphery mantra, these scholars are beginning to map out the complex cultural contours which make up the British World. ${ }^{7}$ A brief examination of this historiography and its reference to empire migration is therefore required to demonstrate how the literature has been shaped and developed over the years. The emphasis here is that during the 1920s divergences between Canadian and British understandings of the competing rationales and mechanics of free and assisted migration became painfully clear to both parties, which by 1930, fostered a greater sense of cooperation between the two imperial partners. This, in turn, will help locate this essay in the evolving British World literature where the migratory processes and the reactions by host societies is at its core.

Ian Drummond's pioneering work published in 1974 remains the benchmark on the mounting tensions and anxieties between Britain and the dominions over the processes by which the empire settlement programme was established. ${ }^{8}$ Since then historians, historical geographers and political scientists have been chipping away at these competing and often contradictory cultural, economic and political crosscurrents involving nation-building and empire. ${ }^{9}$ In recent years, the five volume series of the Oxford History of the British Empire, and more especially its companion series, has sign posted new and exciting research agendas where a comparative approach has been of fundamental importance. ${ }^{10}$ Certainly, for those companion volumes on Canada and Australia, migration has been essential in analysing the journey from 
colony to nation. ${ }^{11}$

Attention has also concentrated upon particular groups of British migrants and specific resettlement schemes which have greatly enhanced the historiography. The scholarship on child migration, youth training schemes, juvenile migration, delinquency and deportation of young people from Canada is enormous. ${ }^{12}$ Religious organisations have received welcome attention too. As well as promoting emigration of the 'right type' from Britain's shores, instilling British values was a central role played by the Church of England, especially on the Canadian prairies; ${ }^{13}$ even if this meant forming an unholy alliance between Protestant clergy and the Ku Klux Klan in 1920s Saskatchewan to promote a 'pure' Anglo-Saxon race. ${ }^{14}$ More recently, the role of women as both agents and cultural guardians in the operation and administration of the migratory process to and in Canada have also been examined. This includes some excellent work on a number of voluntary organizations which either eagerly assisted Ottawa in 'philanthropic policing' by invoking deportation in their ultimate mission of protecting the dominion's racial purity and national character from degenerate 'foreign' influences; or, those like the Salvation Army, which was unwavering in its commitment to see no one deported even if they had committed a moral transgression. ${ }^{15}$

Deportation and the growing medicalization of Canada's immigration regulations throughout the $1920 \mathrm{~s},{ }^{16}$ as we shall see, were powerful weapons in Canada's growing arsenal designed to shield its citizenry from the corrupting influence of the foreign-born. This is not to deny the origins of immigration restriction policies and the use of deportation of various categories of undesirables before 1914. However, their extensive and coordinated use by Ottawa after 1918 
demonstrated a growing confidence in Canada to define and legislate for itself what it believed were suitable categories of immigrant, even when this openly clashed with official British perceptions. The challenge now is to situate this growing corpus of migration literature into what Robert Boyce called the forgotten sources of 'imperial alienation'; seemingly mundane issues which exacerbated relations between London and Ottawa after the Great War. ${ }^{17}$ Empire migration was no exception as it was both a persistent and controversial irritant in Anglo-Canadian relations at this time.

Building upon the scholarly work outlined above, this essay seeks to examine a number of inter-related, inter-connected and sometimes contradictory themes. First, and using the assisted passage scheme for ex-service personnel, it explores how constructive imperialists in Britain and Canada sought to channel the wartime enthusiasm for social reconstruction and regeneration in the immediate aftermath of the Great War to reinforce the physical and psychological bonds of empire. What emerges are that a number of competing political aims and objectives were pursued on both sides of the North Atlantic, which directly impacted on the spirit of empire cooperation that was engendered by the sacrifices made by its citizens in the mud of Flanders, Artois and Picardy between 1914 and 1919. As a result, these vying agendas caused friction in the imperial relationship, especially during the years framed by the 1923 and 1926 imperial conferences, which threatened to undermine the overall aim of binding the two countries closer together. Running in tandem with the investigation of the social and cultural underpinnings of empire settlement, is the examination of some of these policies, their successes and failures, and above all their impact on Anglo-Canadian relations. By analysing this intriguing but underresearched aspect in the evolving relationship between Britain and Canada, new light 
is shed on a pivotal period when the dominions, led by a restless Canada, became equal partners in a newly emerging Empire-Commonwealth.

\section{II}

The campaign to reinforce Canada's Anglo-Saxon character through a selective immigration policy was a potent, ideological weapon in certain sectors of Canadian society. Nativist sentiment, fuelled by racial prejudice, was rampant, particularly in western Canada where many trades unionists and farmers had developed a hostile attitude towards 'alien' immigrants. Take for example, the perspective of J. H. McCulloch, editor-in-chief of the Farmer's Advocate, published in Winnipeg, Manitoba. He told the leader of the Liberal party, William Lyon Mackenzie King, that bringing European peasants to western Canada and 'conducting a brass band campaign in the United States', would merely cause trouble. 'We do not want any more European peasants - for the present at least. An influx of such immigrants, I am positive, would inflame the farmers of Western Canada. What we need is a steady stream of selected British immigrants [especially] experienced farmers, possessing capital' ${ }^{18}$

Anxieties and emotions ran high during the increasingly turbulent, sometimes violent, labor unrest which engulfed Canada between 1917 and 1919. Indeed, the spectres of unemployment, economic depression, and social unrest which followed in the wake of peace galvanized the various nativist associations to combat the largely imaginary threat from within. ${ }^{19}$ In many cases recently returned veterans spearheaded anti-alien agitation and by 1918 the Great War Veterans' Association had eagerly accepted the national leadership of the alien question in Canada. ${ }^{20}$ This anti-alien 
campaign, however, was not simply about keeping undesirable East Europeans out of Canada. It was about safeguarding Canada's moral and social fabric, and its destiny as a newly-emerging sovereign nation. This post-war malaise, as Tom Mitchell has argued, was interpreted by influential elements within Canada's business elite and their socially conscious middle class allies as a 'crisis of citizenship'. ${ }^{21}$

Although social compatibility and the willingness to adopt the Canadian way of life increased in importance they did not supplant the need to attract a skilled workforce as the main criteria behind Ottawa's immigration policy in the immediate postwar years. As Canada's immigration policy became more restrictive, tinged as it was with increasing degrees of xenophobia, its architects nevertheless maintained that with a return to normality Canada would secure sufficient numbers of agricultural and industrial workers either domestically or from the preferred nations of the United States, Scandinavia or Great Britain. However, initial expectations quickly evaporated as the economic circumstances of the 1920s limited the scope and success of the policy. In 1919, the optimistic assumption that British immigration would return to its pre-war levels was quickly dispelled. Eventually, over the course of the 1920s, so too, did the expectations of achieving a culturally homogenous Canada rooted in the institutions of an Anglo-Saxon legacy.

Yet in the immediate aftermath of the Great War, there were few, if any, indications on either side of the Atlantic that the pre-1914 flood tide of British migrants would not return. Moreover, the war itself had provided fertile ground for creative ideas directed towards new paths in social planning, reconstruction, selfsufficiency and empire unity. Buoyed by this wartime enthusiasm for increased imperial cooperation, social imperialists like Lord Alfred Milner, colonial secretary 
between 1919 and 1921, sought to reinvigorate the empire as an aegis of British ideals and democracy. ${ }^{22}$ Under the banner of constructive imperialism, his protégé and under-secretary, Leo Amery, implemented one of the few high-minded imperial projects to survive the war. Established in January 1919, and itself a creation of wartime imperial cooperation, the Overseas Settlement Committee (OSC) became an important instrument in reinforcing the bonds of kith and kin. ${ }^{23}$

One of the first groups singled out by the OSC for assistance were the hundreds of thousands of British ex-servicemen and women who were seen as vital in buttressing Britishness overseas. Even the Canadians, who had never been keen on free or assisted passage, agreed that granting free passage to those who had unselfishly defended the empire in its hour of need was a well-deserved exception to the general rule. However, Ottawa insisted on one important stipulation: demobilized soldiers would be granted free passage only if they came to Canada to settle on the land. This pre-condition, lamented the Toronto Star in June 1920, was having a negative effect on the large numbers of eager ex-service personnel wanting to come to Canada but who did not want to homestead. It decried that less than 4,000 out of a possible four million discharged soldiers had settled in the overseas dominions under the free passage provisions. ${ }^{24}$ Unfortunately for officials in both countries the ex-servicemen's free passage scheme, which operated between 1919 and March 1924, also failed to live up to both the numerical and ideological expectations. ${ }^{25}$

Throughout the 1920s, most British politicians were slow to recognize that Canada wanted settlers of independent means, people who could make an immediate contribution to the economic well-being of the country, and crucially, would not become a burden on government resources. The granting of free passage solely on the 
criteria of war service - however noble the gesture - did not make economic sense. In the spring of 1920, reports from Hamilton and Toronto warned that a large number of penniless British ex-servicemen, many with physical and mental disabilities incurred during the war, had landed in Canada and had become a public charge soon after their arrival. In Vancouver it was reported that at least 150 ex-imperials had been left stranded; and several had already suffered the humiliation of deportation. F. C. Blair, secretary of the department of immigration and colonization, argued forcefully that Canada's deteriorating economic circumstances necessitated the adoption of a well defined entry policy. 'We are supposed to understand the labour market of this country and we are morally obliged to protect not only the workers already here, but even more so the workers seeking to come' ${ }^{26}$

Therefore, in May 1920, when Ottawa announced that it was prepared under the provisions of the ex-service free passage scheme to encourage only agriculturists, household workers and such skilled workers as could not be secured in Canada, Blair was articulating the competing interests which would hound Anglo-Canadian relations over empire migration. 'To relax our policy opens the door wider than I think it is wise to open it at the present time. It is an admission that we are encouraging the immigration of all classes outside and beyond the three classes above referred to. I do not think we can afford to adopt this [laissez faire] attitude... ${ }^{27}$ Many in Ottawa agreed with Blair's insistence that Canada - and Canada alone - had the right to control who entered the country, whatever the countervailing pressures from London. Empire migration had become an ideological battleground for competing dominion and imperial interests which sought to mould and shape policy in accordance with their respective domestic political agendas. 
The poor results achieved under the ex-servicemen's free passage scheme raised doubts in the minds of a growing number of Whitehall officials about Canadian attitudes towards assisted immigration in general and British immigration in particular. The 15 percent fall in emigration from Britain to Canada, recorded in 1922-3, seemed to confirm these suspicions. However, in 1923 Prime Minister Mackenzie King and his Liberal administration took steps to cooperate with the British government under the auspices of the Empire Settlement Act, a landmark piece of legislation inaugurated in 1922, which extended free passage assistance to civil migration for the next fifteen years. Yet, why the sudden change in Canadian attitudes and policy? Important changes had taken place in the Canadian domestic arena. First, the economy began to turn itself around after the short, sharp post-war depression of 1920-2. More importantly, the predominantly rural-based Progressive party, ${ }^{28}$ whom King relied on for parliamentary support and which had been hostile to all expenditure on immigration, experienced a change of heart. Fearful of rural depopulation, particularly on the prairies, party leaders were scared that the Progressive's political power base would be eroded, subsequently weakening rural Canada's voice in Ottawa. Moreover, many Canadians had been lured southward during the depression of 19202. The Dillingham Law (1923), which introduced a quota system, effectively shut American borders to foreign immigrants, but not Canadians. Nativists feared that Canada would be left with the dross of recent European arrivals while Canadians fled in droves to find better paying jobs in the United States.

Ottawa, in fact, had much to be alarmed about. In 1900, Canadians were the 
third largest ethnic group in the United States, after the Irish and German communities. Between 1861 and 1931 it has been estimated that the net migration of Canadian-born to the United States was a staggering 2,080,000. Even more striking by 1900 , there were 788,000 Anglo-Canadians living south of the border making up 8 percent of America's foreign-born. As one Canadian geographer has so aptly put it, this invisible migration of over two million Canadians to the United States had occurred 'with scarcely a ripple'. ${ }^{29}$ The haemorrhaging of the nation's life-blood southward combined with the massive influx of immigrants into Canada whose origins were not Anglo-Saxon alarmed many Canadians who feared that, if left unchecked could lead to the balkanization of the young dominion. Not surprising then, that throughout 1923 demands increased for a concerted immigration policy aimed at attracting quality British settlers to counteract the problem. ${ }^{30}$ Endeavours to stimulate British immigration had become a lively topic across the dominion, where British migrants of the 'old breed, self-reliant and adaptable' would be privileged. ${ }^{31}$ Emphasizing that the first step of the new policy would be to make a careful survey of the countries from which it was proposed to draw settlers, Charles Stewart, acting federal minister of immigration and colonization, announced that a second key step was to hold a conference of immigration officials and field workers at which 'each year's programme would be mapped out'. ${ }^{32}$ W. J. Black, the deputy minister of immigration and colonization welcomed this positive stance. Over the past two to three years he admitted that the various agencies in his department had been engaged mainly in restricting the emigration of those who would have increased the ranks of the unemployed in Canada. Complaining that 'too little has been done to encourage those of a class who at any time could have been assimilated', he was equally critical 
that hardly any migration propaganda had been carried out in the British Isles over the past year. In his judgment this had been a grave mistake as there were 'substantial reasons, other than from an emigration standpoint, why this country should be kept before the British people'. ${ }^{33}$ The prominence given to selected immigration and land settlement by Ottawa reflected that immigration was still seen as the cure-all for Canada's financial troubles, which had been exacerbated by a sizeable war debt. Quite simply, a larger population would disperse the burden of national debt more widely and generate increased government receipts in the future. ${ }^{34}$

Reforms were also made in London to better coordinate Canadian migration policy. In February 1922, Sir George Perley stepped down as Canada’s high commissioner in London. He was replaced by the prominent Ontario Liberal and former vice-president of the Salada Tea Company, Peter C. Larkin (1922-30). The change of personnel provided Mackenzie King with an opportunity, based on grounds of economy and efficiency, to reign in a number of government departments who had separate offices in London, which, he claimed, had become practically independent from the high commission. These departments, whose offices were scattered around central London, included immigration, the board of pension commissioners, trade and commerce, and soldiers' civil re-establishment. Ideally, Ottawa wanted all these operations concentrated under one roof, and Larkin was determined to find savings wherever he could; particularly in the London emigration office which alone employed fifty-four staff out of a total of 103 nation-wide. ${ }^{35}$ This centralization would not happen until June 1925 when everyone was relocated to Trafalgar Square upon the completion of Canada House - christened 'Larkin's folly' by many Canadians resident in London. ${ }^{36}$ Nevertheless, Larkin was determined to get to grips with the sprawling 
bureaucracy.

At first, the results were encouraging. The British press devoted wide coverage to Canada's change in attitude and the renewed interest was demonstrated by a 100 percent increase in British emigration during 1923-4. Heartened by its success, the Canadian government embarked upon a policy of preference for British immigrants on the Atlantic routes. One obvious indicator of Canada's increased immigration activities, primarily directed at farming opportunities in the dominion, was the huge injection of money into its advertizing and publicity campaigns for 1923: $\$ 760,000$ up from $\$ 350,000$ the year before. ${ }^{37}$ The high commissioner also became more involved. Larkin, who found public speaking difficult, was kept busy on emigration work throughout 1923 . 'I have always advocated strongly the emigration of people willing to work on the land', he wrote to Mackenzie King in May, 'and lately [I] have been adding that builders and building employees are also badly wanted' ${ }^{38}$

There was another reason why Larkin was focusing on emigration in his public speeches. The ever sensitive King had received a number of reports that his political opponents in both Britain and Canada were beginning a whispering campaign, claiming that immigration from the United Kingdom was not desired by his administration. It was further rumoured that Larkin, in private conversations with British officials, was confirming that this was in fact the case. King instructed Larkin that the matter had become serious enough to warrant a counter-offensive. When the appropriate occasions presented it, Larkin was to make a series of public statements on Canada's desire to receive, 'in large numbers as may find it possible to come, the right class of immigrants, from the British Isles'. As the 'busy-bodies are at work 
seeking to sow seeds of distrust', and in advance of the Imperial Economic Conference to be held later in the year, the prime minister had thought it well not to delay bringing this matter to Larkin's attention. ${ }^{39}$ Over the next several months Larkin - who was personally not in favour of assisted migration because this category of settler was adjudged to be physically and mentally weaker than those who had independent means - made several high profile speeches on Canadian immigration policy emphasizing Canada's desire to obtain the 'right classes' of immigrant. King called them timely and thought they had wrong footed the whisperers and their negative propaganda campaign that was creating prejudice against the Canadian government and its high commissioner. ${ }^{40}$

Although assisted immigration rose, the overall results were disappointing as the total number of British immigrants declined by 38 percent in 1924-5. ${ }^{41}$ This was immediately seized upon by British officials for two reasons. There were 1.5 million unemployed in the United Kingdom and indications were it would deepen with the onset of winter. This and the worsening economic situation enshrouded the six weeks of proceedings at the Imperial Economic Conference held in London between October-November 1923. Mackenzie King, in conversations with the British prime minister Stanley Baldwin, recorded in his diary at the beginning of the conference that Baldwin was keen to work with the dominions in solving some of the economic woes which the empire faced. Encouraged by the good will and positive response of the dominion leaders to Britain's plight, he told King that a crucial step along the road to recovery was that Britain 'must get rid of some of her population' ${ }^{42}$ However, no firm promises or initiatives were finalized because Baldwin called a snap election shortly after the conference. His defeat and the coming to power of Ramsay 
MacDonald's short-lived Labour government did not change the growing British criticism of Canada's restrictive immigration policy. Lucien Pacaud, Larkin's secretary in London, informed Mackenzie King's private secretary, F. A. McGregor, that MacDonald warned the dominion high commissioners that if there was to be any large-scale emigration from Britain, that the dominions 'must be prepared to accept representatives of the mass of the population rather than continue the present system of selecting only the best and most skilled' ${ }^{43}$

This would never happen. Canada had its own economic problems. Besides, as Blair outlined to O. D. Skelton, the newly appointed under-secretary of state for external affairs, even if Canada tried to inaugurate the settlement of 50,000 British settlers on individual holdings in 1924, it was an impossible task. For one, the administrative machinery was simply not there. Secondly, at a time when free homestead lands were not in the quantities they were prior to 1914, when railway construction was slow and investment capital scarce, without state aided settlement the difficulties of settling such large numbers were magnified. Finally, Blair insisted that whether the intending settler had capital or not, it was essential that he should gain experience in Canadian agricultural methods before undertaking settlement on his own. Blair concluded that '[c]arefully planned settlement will produce results which will be cumulative', ${ }^{44}$ but it took time and patience. This was something British officials (and migrants) consistently failed to appreciate.

The second criticism levelled at Canada's immigration policies by some British commentators in the mid-1920s was that the increased screening and regulation of the types and numbers of British migrants the dominion was prepared to take was having a detrimental affect on the purity of its Anglo-Saxon stock. During a 
tour of Canada in the autumn of 1925 one observer recorded that there was 'a general feeling in Canada that the present immigration policy is failing. The weak point is the proportion between British and Foreign born immigrants, rather than the total number of immigrants...If Canada is to remain British in sentiment, it must remain British in racial origin'. ${ }^{45}$ The Right Reverend Dr G. E. Lloyd, Bishop of Saskatchewan, confirmed these fears. The state of Canada's immigration policy was so unsatisfactory that according to his estimates only 25 percent of the population in western Canada were British. Upon completion of an empire tour in 1926-7, the Bishop of London, the Reverend Arthur Foley Winnington-Ingram, agreed and felt that the British element in the dominion was not strong enough and needed reinforcing. ${ }^{46}$ One thing however was beyond dispute. According to LieutenantColonel J. H. Stanley, the organizing director of the Church of England's Council of Empire Settlement who accompanied the outspoken bishop on his tour, the Church of England had to demonstrate that it could act imperially and hence it 'must leave no efforts untried to bind Canada [closer] to the Mother Country' and keep Canada British at heart. ${ }^{47}$

At one level the Bishop of London's observations about the dilution of the British element in Canada seemed valid. In September 1925, the Liberal government, which was fighting an election campaign, was blackmailed into signing a three-year agreement with Canada's two transcontinental railway companies, the Canadian Pacific Railway (CPR) and the Canadian National Railway, to recruit prospective agriculturalists from the non-preferred immigrant categories. Between 1925 and 1930 (after the extension of the agreement in September 1928) approximately 185,000 people from Russia, the Baltic States, central and south-eastern Europe entered 
Canada under the terms of the controversial agreement. Even the religious sects such as the Mennonites and Hutterites, excluded in 1919, were begrudgingly welcomed back. Representatives of these companies were given the authority to issue occupational certificates and entry permits, which officials at the department of immigration and colonization claimed not only undermined their authority in these matters; but, it was alleged, the policy was a sinister attempt by the railway companies to demolish Canada's selective immigration policy. Public reaction was mixed, but as the decade advanced and the economy showed signs of flagging, the Canadian Conservative party under the leadership of R. B. Bennett used this issue as a club with which to attack King's Liberals. Bennett charged that immigration could not be left to private sector interests. Moreover, these immigrants posed a serious threat to Canada's Anglo-Saxon character. ${ }^{48}$

These criticisms chimed with more disturbing news reaching Ottawa in August 1927 that the Ku Klux Klan and the Orange Order were spreading propaganda throughout the prairies, especially in Saskatchewan, that the Catholic Church was controlling the activities of both the federal and provincial governments. The Liberal premier of Saskatchewan, Jimmy Gardiner, was unsure if any political harm would befall either the federal or provincial Liberals, but this anti-Catholic campaign, much of which was directed at the large influx of Ukrainians, was worrying nonetheless. ${ }^{49}$ This alarmism was tempered somewhat by the observations of Canada's governorgeneral, Lord Willingdon, after his tour to western Canada in the spring of 1927, where he found a 'most splendid spirit and atmosphere'. ${ }^{50}$ A year later in the rapidly developing Peace River country of north-western Alberta, he had found very few southern Europeans. Settlers were of the 'right sort', with the basis of development 
and the settlers' sentiment 'strongly British'. ${ }^{51}$ Willingdon reported to Amery that all the warnings he had heard about the want of loyalty on the prairies were really 'all moonshine'. For he had found the 'most wonderful loyalty and welcome' wherever he had travelled. 'Of course', he cautioned, 'it is a fact that if economic conditions are good, the possibilities and probabilities of agitation are minimised and people are inclined to be satisfied' ${ }^{52}$

However, Whitehall's worst fears seemed to be confirmed when the department of immigration and colonization released its annual report for 1926. It noted that for the first time since 1902 British immigration was surpassed by foreign intake. ${ }^{53}$ This was indeed a worrying trend to one senior official in the dominion land settlement branch and a former chairman of the Soldier Settlement Board, Major John Barnett. In his opinion, 'unless very definite action is taken to stimulate the flow of British people to Canada in the immediate future I feel that the Empire interests [sic] in North America are going to suffer very seriously'. Barnett was also alarmed that Ottawa was showing little interest in immigration matters, lamenting that whatever steps were taken would have to be initiated by the British. Furthermore, progress would only be achieved by initiating schemes through provincial auspices rather than through the federal government. ${ }^{54}$

Equally blistering criticisms were being levelled against ministers in Ottawa and high commissioner Larkin by senior immigration staff in London. J. Obed Smith and J. Bruce Walker were exceptionally critical of those at the helm. Upon his retirement in late 1924 as superintendent of emigration for Canada in London, Obed Smith charged that there was a distinct lack of enterprise and esprit de corps in Ottawa which he felt had undermined his work in Great Britain in recent years. Despite the 
doubling of the advertising budget for the 1924 season, he alleged that efforts were being hampered by what he claimed were ineffective propaganda strategies. Furthermore, he charged that no one in authority understood this vital element of immigration work. Walker, who replaced Smith and became Canada's director of European emigration, agreed claiming that the deputy minister of immigration and colonization, W. J. Egan, knew nothing about 'the science of advertising, and thinks money for that purpose is practically wasted'. Larkin, in Walker's eyes, was equally ignorant of the need to advertise, despite his long career in business. He 'thinks advertising Salada tea and the Dominion of Canada [are] two different things' ${ }^{55}$ There was another depressing trend in British migration patterns to Canada. 'There is an aspect to the phase of the Immigration problem one can hardly mention in public', confided Robert Forke, the minister of immigration and colonization, to J. W. Dafoe, editor of the influential Manitoba Free Press, 'and that is that our English immigrants do not stay on the land'. ${ }^{56}$ As one disgruntled British official wrote:

In a sense we have to face a crisis in our relations with Canada over the Empire Settlement Act. We, on the one side, want to put most of our money into assisted passage, training and aftercare. They, on the other hand, have made it clear to us that they consider the assistance on passages should be lessened and that all the money we have to spend should go into land settlement. ${ }^{57}$

Amery, appointed as secretary of state for both the colonial and dominions offices with Stanley Baldwin's re-election in November 1924, was much more critical of 
Canadian attitudes and policies. In January 1925 he told Willingdon's controversial predecessor as governor-general, Lord Byng of Vimy, that he despaired about Canadian attitudes towards promoting British migration to the dominion. 'I cannot help feeling that there is a certain lack of the sense of proportion in dealing with this matter'. However excellent Ottawa's announcement that it would initiate a government-sponsored programme designed to settle 3,000 British farming families, this was not going to 'build up the country very fast as against an exodus of two or three hundred thousand across the [United States] border' ${ }^{58}$ Furthermore, despite the Canadian government's renewed interest in promoting British immigration, he believed that the isolationist Mackenzie King and the uninspiring Egan, were the main obstacles preventing greater co-operation and co-ordination between the two governments. After all, many leading British politicians knew King to be 'a slippery customer and very weak in his Imperial faith'. ${ }^{59}$

The most serious irritant between Britain and Canada was the latter's stringent medical requirements. British authorities alleged that Canadian immigration officials were over-zealous in carrying out medical examinations. On the surface, there was a grain of truth to these charges. The 1920 s witnessed a steady stream of regulations designed to curb the entry of a host of undesirable elements. Alcoholics, conspirators, and illiterates were denied entry after 1919. Asian and black immigration was nonexistent. To ensure that these and other non-preferred races were discouraged, J. D. Pagé, a long-standing medical superintendent, suggested to the deputy minister of health, Dr J. A. Amyot, that Canadian immigration officials adopt the very successful American practice of daylight inspection for all examination work. Not only would this make the inspection process more efficient; but 'daylight is necessary to enable an 
Immigration Inspector to appreciate the significance of the hue of the people passing before him when it may be the only sign that may lead him to detect some serious underlying conditions' ${ }^{60}$

\section{IV}

Problems continued to plague Anglo-Canadian attempts to promote overseas settlement and migration. Despite the increase in assisted immigration after 1925, as a result of an agreement signed between the two governments and the shipping companies which reduced Atlantic fares by 80 percent, it was clear that the type of British immigrant arriving in Canada was unsuited or unwilling to embark upon an agricultural career. Amery, for one, had always advocated the need for some form of preliminary farm training in the United Kingdom before any emigrant's departure to Canada. Throughout 1926, in conversations with senior Canadian politicians and business leaders, he continually reiterated the need for closer cooperation in this allimportant aspect. In March 1926 he chatted to that 'vain old bore', the leading Liberal senator, Raoul Dandurand, 'who was full of talk' about the need for training British migrants prior to their departure for Canada. Amery quipped: 'I wonder how far he really wants them! ${ }^{61}$

Next month, during a lunch hosted by Amery at his London residence in Eaton Square, a number of officials from the Canadian high commission and OSC were invited to discuss migration issues. Although no definite conclusions were reached, there was a consensus that the 'senior dominion' could take 'an unlimited number of youths' whom would first be given some preliminary training in agriculture. 'It is interesting to see', recorded Amery, 'that the Dominions have now generally swung 
round to the idea of some sort of training here which they always rejected before'. ${ }^{62}$ However, that October, when Amery intervened during a meeting of the OSC with an appeal that the dominions share in the cost of training, Blair, who was in attendance, answered in a 'very flat negative'. ${ }^{63}$ Ottawa's intransigence was becoming frustrating. In a conversation with Edward Beatty, chairman of the CPR, and whose company was a major player in migration and settlement, Amery spoke 'very frankly' about Canada's abject failure to do anything effective in the way of promoting British migration. Beatty agreed, emphasizing the need for a Canadian government with some convictions. ${ }^{64}$

Unfortunately for Amery, events were to conspire against him; events which reinforced Canada's increasingly restrictive immigration stance. The General Strike of 1926, caused by an acrimonious coal strike which long outlasted it, not only undermined the United Kingdom's economic recovery, but it also seriously impacted upon empire settlement. Protracted difficulties in the coal industry meant that there would be a substantial deficit at the close of the 1925-6 fiscal year. Furthermore, it was predicted that there was a real possibility that these difficulties would carry over into the next making it hard for the British government to balance revenue and expenditure. These unforeseen difficulties necessitated restrictions on government spending, and hence, impinged on the dominions office's capacity to fulfil all of its empire settlement projects, including the establishment of its UK-based settler training and migrant testing centres, many of which were aimed at unemployed coal miners. All that the dominions office could do for its 1926-7 projections was to 'express a pious hope that the desired centres may be started as soon as financial exigencies permit' ${ }^{65}$ 
'The problem', according to one dominions office memorandum, 'is to convert a large part of our industrialized population into a rural population engaged in agriculture'. ${ }^{66}$ As a result, in September 1926 the chairman of the OSC, Lord Clarendon, and his deputy, T. C. Macnaghten, met with Egan and his officials in Ottawa to explore this very issue. High on the agenda were those opportunities for British migrants other than farm workers, such as coal miners, construction workers, and general laborers. Clarendon noted that there was great demand for labor in northern Canada's 'bush' camps. Ottawa had been diligently trying to persuade Canadian transportation companies to secure suitable British settlers for this type of work. However, several unnamed companies considered British settlers ill-adapted to 'bush' work, as many could not handle an axe. ${ }^{67}$ Although no 'spectacular' progress was accomplished during the conference, Clarendon was convinced that meeting around a table tackling immigration problems face-to-face created a better understanding between the two parties that extensive letter writing could never accomplish. ${ }^{68}$ The fact remained however that bridging the conceptual gap that existed between the two countries over appropriate migration strategies was going to take more than the occasional face-to-face meeting.

Equally challenging for the British government was to overcome the 'mistaken belief' that migration was simply a cure for the United Kingdom's unemployment. In a long and detailed rebuttal by the ministry of labour, which challenged the need for state-aided migration, officials noted how the British government was 'being continually pressed to adopt grandiose schemes of overseas settlement in order to increase the numbers who migrate'. Within the same breath it noted one of the great ironies underpinning state-aided migration to Canada: 'there is something lacking in a 
policy of State-assisted migration when, as in the case of Canada, more people go out without assistance than with assistance'. If anything, according to the ministry of labour, there had been a decrease in migration with the empire since the Great War. Even more damning, there had been no substantial increase in numbers since the enactment of the Empire Settlement Act in $1922 .{ }^{69}$

More searching questions were asked by the ministry of labour, which probed further Amery's and the dominions office's seemingly unswerving support for stateaided migration. For it, the central defect of the 1922 Act, and any scheme of stateassisted migration where central government was required to find a substantial proportion of a migrant's travel costs, was that migration became 'subjected to all manner of capricious political restrictions', many of which were founded upon a completely false economic basis. 'As the Act is administered between Governments it is necessary for Governments to respect each other's political difficulties'. ${ }^{70}$

The dominions, like the rest of the world, had experienced trade dislocation after the Great War. This had resulted in considerable intermittent employment and unemployment, mainly in the cities, 'in itself a powerful deterrent to migration'. This, argued ministry of labour officials, was naturally accompanied by a strengthening of the political power of the labor movement in the dominions, especially Australia, which was anxious to safeguard their members from a possible flooding of the employment market and a downward pressure on wages. Therefore it was not surprising that the dominions would be sensitive to domestic trade union pressure and hence were bound to be restrictive when it came to official migration policies. ${ }^{71}$ This did not mean that Britain's industrial or urban unemployed were prevented from immigrating to Canada. Provided they were healthy and had previous agricultural 
experience or training, no limitations were placed upon them. However, in the depressed industries such as textiles, shipbuilding, and coal mining the ministry of labour seriously doubted that previous agricultural experience was likely to be found in many cases. Such restrictions meant that the numbers of men from these occupations who thought they had a chance of breaking out of their present economic circumstances through assisted migration to Canada was limited by the capacity of the British government to finance requisite training schemes. ${ }^{72}$ Ironically, the General Strike of 1926 had put pay to most of these initiatives.

If the ministry of labour's stinging analyses were not enough to dampen dominions office enthusiasm, in May 1927, the Free Press Evening Bulletin headlined a bizarre incident involving two British Great War pensioners who were enroute to Canada to start a new life. The two veterans were alleged to have used revolvers to shoot seagulls during the voyage. Both men, who had purchased these weapons prior to embarkation, were promptly relieved of the firearms by immigration officials upon their arrival in Canada. However, the Bulletin could not resist taking what was now a familiar jibe at the British migrants' ignorance of their new environment.

What foresight and ... knowledge of Canadian conditions is shown in the apportioning of forty-five dollars for revolvers! And this is part of the plan to protect the funds of the pensioners and see that they are not spent improperly! ... In some official quarters in Britain there must be a weird idea of the dangers in Canada from bears, from warlike Indians or from outlaws in the less settled parts...With such a great desire in both countries to promote British emigration to Canada, it is surprising 
that there should be such lack of understanding of conditions in Canada. $^{73}$

Undaunted, Amery hoped that his forthcoming 'Empire pilgrimage', ${ }^{74}$ which began in July 1927, would help becalm these troubled migration waters. When he returned home in February 1928 he confided in his diary that he thought he had made real progress in Canada, 'more perhaps than anywhere else except possibly South Africa, in quickening the consciousness of Empire and the sense of its possibilities' ${ }^{75}$ To His Majesty King George V, however, he admitted that he had been rather anxious about the Canadian part of the tour, as in Canada, more than anywhere else it was difficult 'to avoid saying nothing without getting into controversy'. Amery noted that Prime Minister King had been 'most friendly, indeed, delighted with everything I said, and we had some most useful talks. He is a man whom one can only deal with in conversation', observed Amery. ${ }^{76}$ Impressed with the calibre of most of King's cabinet, he was roundly disappointed with the minister of immigration, Robert Forke, a farmer from Pipestone, Manitoba, and leader of the Progressive party. In Amery's opinion, Forke was the 'weakest vessel' in the Canadian cabinet, and one who unfortunately, was 'entirely under the thumb of his Deputy Minister, Egan, an able Irish Catholic bureaucrat whose whole outlook on the [migration] problem is negative'. ${ }^{77}$

Amery's perception that his proto-Keynesian ideas on bringing the empire closer together through imperial preference, protectionism and increased migration had been received favourably in the dominions, including Canada, were quickly dispelled however by British newspaper reports that Ottawa was to introduce a new, 
more restrictive set of entry regulations in the coming season. The Times feared that these regulations would reduce British emigration to Canada between 30 and 50 percent. ${ }^{78}$ The row centred upon the introduction of a fresh set of medical guidelines and procedures. Previously, those intending to migrate to Canada had to either undergo a medical examination, which was performed in the United Kingdom by a roster of approximately 1,500 British doctors, or subject themselves to an examination upon arrival in Canada. This system was to be replaced in mid-February 1928 by a compulsory examination prior to embarkation by one of a team of only eighteen Canadian doctors contracted by Ottawa and coordinated by the chief medical officer based at the high commission in London. Furthermore, all British migrants, whether under assisted schemes or at their own expense, were obliged to undergo a thorough medical examination at a predetermined time at one of the designated medical centres which the Canadian doctors would visit at regular intervals. The Times complained that many people who wished to go out and settle in Canada 'would hesitate before going and submitting themselves, their wives, and their children to examination by a strange doctor in a strange place'. Delays would be inevitable, it remonstrated, and there was no guarantee that the examinations would be completed in one day if the medical examiner had scores of applicants to process. This would either force many candidates to stay overnight, incurring the added expense and inconvenience of finding food and lodging for themselves and their families in an 'undesirable place'; ${ }^{79}$ or, as one editorial in the Western Daily Press protested, applicants would have to suffer the vexation of queuing only to have their examination postponed for several weeks, forcing them to make another journey. ${ }^{80}$ The Morning Post was more hypercritical. It claimed that the elaborate new medical machinery covered 'some political 
design against British emigrants' ${ }^{81}$

These misgivings about the new regulations and the discouraging message they were sending to respectable, would-be applicants echoed throughout a number of provincial newspapers, many of which were located in prime recruiting areas. In Scotland, the Greenock Telegraph claimed that the new system was a barrier to emigration. Although it commended the implementation of a more thorough medical examination at British ports of embarkation - thus preventing 'unnecessary suffering and inconvenience' for those who in the past had been turned away upon their arrival in Canada and had been deported 'homeless and workless' - the crucial defect, it alleged, was that the intending settlers had to answer in triplicate some ninety questions and produce identification forms containing a photograph before undergoing the physical examination. ${ }^{82}$ The Shipping World insisted that Canada had made a grave mistake in 'introducing an irritating scheme of medical examination of prospective migrants, and insisting upon the production of a passport with a portrait'. The Glasgow Evening News decried that 'apparently the Canadians are not satisfied now that we are giving them the very best plums in our basket... Hunting the Canadian Doctor is a new sport our people will have to train for more actively than tossing the caber, and for the tug-of-war at Highland gatherings' ${ }^{83}$

The competing and, at times, contradictory interests which underpinned the growing tensions witnessed in Anglo-Canadian relations concerning migration and overseas settlement continued to be played out at the highest governmental levels throughout 1928. In early August, after several delays, Lord Lovat, the chairman of the OSC and parliamentary under-secretary of the colonial office, arrived in Canada to discuss how best to increase British migration to the 'senior dominion'. Accompanied 
by G. F. Plant, the secretary of the OSC (who was to return home after the Canadian leg), and Francis Skevington, a principal secretary at the treasury and its representative on the OSC, at the top of Lovat's agenda was Canada's new medical regulations. According to William Noxon, the Ontario agent-general in London, the overwhelming view in Britain was that the extremely selective immigration regulations combined with the thorough medical inspections now required before embarkation was proof positive that Canada did not want British migrants. ${ }^{84}$

The introduction in February 1928 of the new system of compulsory medical inspection prior to departure had been discussed by Canadian officials at the departments of health, and immigration and colonization ever since 1926. At first only those under government-assisted passage schemes such as children and unaccompanied women would be obliged to undergo the compulsory medical examination. This comprised about one-quarter of all British arrivals in 1926-7. Additional funds were allocated to augment the new system, which Ottawa hoped would make the entire process more efficient and cost effective. ${ }^{85}$ An internal review carried out in April 1928 by A. L. Jolliffe, commissioner of immigration in London, concluded that despite the adverse publicity in the British press over the past winter the new system of medical inspection was working well. Furthermore he had failed to discover any evidence that the procedures now in effect were acting as a deterrent to immigration. Admittedly, there were valid complaints over the new inspection system, which many migrants found inconvenient. The high commission responded by introducing several steps to improve the service; such as keeping longer hours in some examination centres plus adding twenty doctors to the register to increase geographic cover and range. Jolliffe concluded that when compared with figures from 
early 1927, the Canadian doctors had examined 1,000 more assisted migrants than their British counterparts had on the old roster system the year before. If the numbers of enquiries were up, argued Jolliffe, this hardly signified that the new regulations were dragging numbers down. Confident that the new system was working much more effectively, he told Egan, that the list of difficulties he had investigated were in his opinion 'to a large extent anticipations rather than realities' ${ }^{86}$

When Lovat met with Canadian officials in Ottawa in late August 1928 he unveiled his plans to stimulate a major land settlement project aimed at settling British miners on farms in Canada. Arguing that there was 'a large supply of really suitable persons' in the United Kingdom, he revealed that the British cabinet had sanctioned an additional $£ 600,000$ outside the normal expenditure on overseas settlement, training and reduced passage. The conference minutes reveal detailed and wideranging discussions on a host of immigration schemes and issues. One key success was an agreement to continue giving preference to British migrants by reducing transAtlantic tariffs to $£ 10$ for third-class fares. Another involved the thorny issue over the deportation of unwed mothers. Egan stated that everything possible was done to avoid the deportation of these women, 'unless there was evidence of constant immorality and of disease'. For instance, he pointed out that for every 100 deportation orders issued in this category only a small percentage were ever executed. When Lovat tried to tackle his Canadian hosts by the wholesale condemnation of the new medical inspection system, and suggested that the examinations be carried out by British doctors, he got nowhere. Ottawa stood resolute in its determination to control this process. $^{87}$

Frustrated by Ottawa's intransigence to embark upon 'big' colony schemes, or 
allow an increased role for voluntary organizations, Lovat had to remain content that some progress had been made in further developing current empire migration policy. At the very least, during the two months he spent in Canada it had allowed him to make a ten-day trip to the Peace River country in north-western Alberta, and to visit a few of the sponsored settlements dotted throughout the prairies; especially the Clandonald colony at Vermilion, Alberta, inaugurated by the Scottish Immigrant Aid Society and established in partnership with the CPR, where 100 Scottish families had been settled on 100 purpose-built farms. ${ }^{88}$ In the end, however, Lovat's trip to Canada had been largely unsuccessful, which was to be compounded by the miserable failure of the 1928 miner-harvesters' scheme. ${ }^{89}$ Worn out, he left Canada in early October for New Zealand, where ill health forced him to truncate his New Zealand tour and cancel his onward journey to Australia. ${ }^{90}$

To make matters worse, in July 1929, Sir William Clark, Britain's first high commissioner in Canada - and the new conduit between the two governments involving migration matters - reported a candid conversation he had had with Egan. The deputy minister revealed to Clark that he had always been opposed to assisted migration. He claimed that from the very beginning the grant of assistance would be fatal for the development of immigration from the United Kingdom. In the last two years alone, public opinion throughout Canada had crystallized and had become increasingly vocal against assisted migration. A similar trend had been mirrored over the past several years in the debates within the Canadian House of Commons. Furthermore, Egan firmly believed that assisted migration produced a less reliable type of immigrant, which was less frequently found among the unassisted. To reinforce his point, he informed Clark that of the 668 deportees recorded in 1928-9, all 
had been British and all had been assisted migrants. ${ }^{91}$ Egan had been stretching the truth here. In 1928-9 there had been a total of 1,964 deportations of which 1,083 or 55 per cent were British, involving both assisted and unassisted migrants.

Nonetheless, despite these modest deportation figures for 1929, the number of deportations involving British migrants, especially those who had been assisted, had been rising steadily throughout the 1920s. For instance, of the total number of British deports for 1929, 61 percent were assisted migrants. ${ }^{92}$

If these figures were depressing, what about the administrative costs involved in settling a British family in Canada? The OSC was informed by the CPR, which operated its own settlement schemes through its subsidiary the Canada Colonization Association, that the costs in settling a British family on the prairies were five times higher than that of a family from continental Europe. Even more alarming, there was a notable decline in the numbers of British settlers participating in these schemes. Of the 2,667 settlers who were assisted by the CPR between 1925 and 1928, only 44 were of British origin. ${ }^{93}$ Canadian departmental figures for 1927 revealed an even more disturbing picture. It was estimated that it cost $\$ 17$ for each migrant from the British Isles to be settled in Canada, compared with just 15 cents for each newcomer from the continent $!^{94}$ The cost of landing one British migrant in Canada was the equivalent of landing 113 central and south-eastern Europeans. By the close of the decade the odds seemed to be stacked against the British government in its desire to increase the flow of its citizens to Canada.

The flurry of British ministerial activity in Canada over the summer and autumn of 1928, and Lovat's idea of a 'big' colony on the Canadian plains was, as Ian Drummond discovered, driven by Whitehall's urgent need to find ways of alleviating 
Britain's chronic unemployment in the run up to a general election. ${ }^{95}$ However, as we have seen, Lovat's scheme was rejected by Ottawa as impracticable and 'politically objectionable'; ${ }^{96}$ thus thwarting the Baldwin government's fantasy that large-scale British migration and settlement to Canada would help solve its deepening unemployment crisis. Interestingly, it was the treasury official, Francis Skevington, who pointed the way forward. Migration, he told his superiors, could not be forced. In the future, as in the past, 'the limits of migration will be set by the openings in the dominions, and that there is little that can be done usefully under the Empire Settlement Act to extend these openings'. What was needed, he argued, was not so much money as the right economic conditions favourable to the growth of population. $^{97}$

The election of Ramsay MacDonald's second administration in May 1929 did not mean that the Labour government had abandoned the idea of working with the dominions to alleviate Britain's unemployment problem. However, a more commonsensical approach had now permeated the corridors of Whitehall. Arthur Ponsonby, the parliamentary under-secretary of state for dominion affairs, was told by the lord privy seal, J. H. Thomas, that: 'I look to Canada as being the most important of all our Dominions in connection with migration, but I cannot too strongly urge that no greater mistake will be made than anyone assuming or even giving colour to the view that migration to the Dominions is to be a solution of our unemployed problem, ${ }^{98}$ Another keen observation was also made by Skevington when he tabled his final report to the dominions office in April 1929. He pointed out that the possibilities of any substantial increase in Canada's capacity to absorb immigrants depended upon the prospects of a more rapid expansion of the manufacturing 
industries. Nonetheless, for many British officials, Canada, of all the dominions, still had the most to offer British migrants and was the only one still willing to settle them on the land at a reasonable cost.

Eager to keep an open dialogue with Ottawa, Thomas announced in the British House of Commons that it was no good talking of self-government to the dominions, nor was it wise to acknowledge that they were 'independent and free', and then criticizing them because they did not do what you had dictated to them. This was a profound mistake (which Baldwin's government had seemingly ignored). Take unemployment, he mused. Nothing but harm would arise by 'letting [the dominions] believe for a moment that you want or are assuming to solve your unemployment problem at their expense. They resent it, and resent it bitterly'. Echoing Amery's message to Baldwin in 1928, Thomas argued that the same equality had to exist when mediating with the dominions over migration; an issue which had to be negotiated on the spot and in person. ${ }^{99}$ This did not stop critics such as George Lansbury, the first commissioner of works. He complained to MacDonald that a bigger effort had to be made over migration and land settlement. If a radical solution was not found and the government failed to help 'develop the land lying idle in the Dominions, then the end of the British Empire [was] not very far off' ${ }^{100}$

Unfortunately for Lansbury and others who were keen to resume large-scale migration to Canada, the timing was inauspicious. When Thomas went to Canada in August 1929 to drum up support for empire settlement his entreaties fell on deaf ears. So, too, did his attempts to persuade Ottawa that British migrants should be given preference over continental immigrants. By now, even the railway companies had decided to abandon their immigration operations; and in January 1930 the federal 
government began contemplating disaggregating itself from land settlement agreements previously negotiated between itself and the British government, shifting the financial burden and administrative responsibilities onto the provincial governments. The Wall Street Crash of September 1929 and rising unemployment in Canada finally stopped any new state-assisted migration initiatives dead in their tracks. By the end of 1930, the newly-elected Conservative government in Canada led by R. B. Bennett was forced to introduce tighter immigration controls. Assisted passage and other betterment schemes were promptly abandoned. ${ }^{101}$

\section{$\mathbf{V}$}

The problem with the British government's attempts to promote increased migration, especially from the urban and industrial areas, was that the association between empire settlement and unemployment created prejudice overseas. Similarly, it was recognized by British officials that the two questions could not be completely dissociated as those who travelled overseas relieved to some extent the domestic situation. This connection had been recognized by the board of trade in 1921 when Amery was preparing the political ground for the Empire Settlement Act. It was desirable to promote emigration 'for Imperial purposes of an economic as well as of a political character' and there was no getting around the fact the inter-relationship between state-aided empire migration and the problems of domestic unemployment. ${ }^{102}$ On the eve of his trip to Canada in 1928, Lovat was similarly cautioned by his close friend Lord Lothian, a former acolyte of Milner and one closely versed in dominion affairs. Lothian warned him that one of the 'troubles' about migration was that the dominions had always been 'approached from the stand point that they ought to help 
Great Britain'. They were naturally on the defensive when asked, conveyed Lothian, therefore growing dominion resistance to migration schemes which promoted the needs of the 'mother country' first should not come as a surprise. ${ }^{103}$

The home secretary, Sir William Joynson-Hicks, made a similar point to Baldwin in the run up to the 1929 general election. He found it most 'disquieting' that the fortunes of the Conservative party were linked to the question of unemployment and empire migration. An attack on the government's unemployment policy was inevitable; and it was therefore essential to use 'our utmost endeavour to render such an attack abortive'. The announcement of a migration agreement with the Canadians would be an invaluable weapon with which to blunt the government's critics. He lamented, however, that 'any land settlement scheme would appear foredoomed to failure if there were any suggestion that it was linked up with the relief of unemployment'. ${ }^{104}$ By the end of the decade the British high commissioner in Ottawa reported to Amery that it was critical to try and keep Britain's migration policy divorced as far as possible from the issue of unemployment. He noted that when immigration from the United Kingdom was discussed in Canada it was invariably referred to in relation to Britain's serious unemployment problem. 'I doubt if it is possible now to alter this impression', he confided. As a countermeasure, he suggested that it would be useful to emphasize domestic training schemes 'as a guarantee that the ex-unemployed, who may come here as migrants, will not only know something about farm work but will also have been "tried out" and their adaptability to land work tested during their period of training'. ${ }^{105}$

Economic factors aside, the failure to establish a landed British yeomanry in Canada after 1918 was in part attributable to the growth of 'sturdy' dominion 
nationalism. E. T. Crutchley, Britain's migration representative in Australia, reported in 1932 that the growth of dominion nationalism in the 1920s, itself strengthened by the equality of status conferred by the 1926 imperial conference and confirmed in the Statute of Westminster in 1931, revealed 'a manifest determination to view questions of population and migration from the national point of view only'. ${ }^{106}$ No longer would the needs of Great Britain dictate migration policy unless it coincided with circumstances or conditions in the dominions that favoured a large incursion of British subjects. As Egan forcefully reminded his prime minister in May 1929: 'The policy of the Department [of Immigration and Colonization] is to secure the largest possible immigration of the classes Canada needs and can assimilate with profit to the newcomer and without loss to Canada. Canada with her vast area, her natural resources and her sparse population needs immigration - not indiscriminate or haphazard immigration but a movement of people who will bear a direct relationship to the opportunity awaiting the newcomer'. ${ }^{107}$

As the economic uncertainties intensified, Ottawa remained adamant that the imposition of tighter entry regulations which restricted access to those immigrants who contributed immediately to industries which suffered from a shortage of experienced manpower was the correct approach. Moreover, the strategy of "passing all immigrants through a fine sieve' was also designed to allay the fears of Canadian labor that staunchly believed that British immigrants competed for jobs, lowered wages, and increased unemployment. However, narrow-minded and uninformed this argument may have been in the minds of many British officials, the fear that British migrants competed with Canadians in a shrinking job market was nonetheless widespread. How prescient therefore was Amery's plea to Baldwin in 1928 that the 
gulf which existed between Canada and the United Kingdom could be bridged only by employing a policy of compromise and indulgence. ${ }^{108}$

What did this mean for fortifying the bonds of Britishness in Canada? Clearly, the findings indicate a variety of tensions and contradictions inherent in the quest for a 'Britannic' identity in 1920s English Canada. Despite the political rhetoric, especially in western Canada, for more British stock to reinforce Anglo-Canadian society from the so-called degenerative hordes from eastern and southern Europe, the stark economic reality was that the type and quality of the British migrant demanded by Canadian farmers, civic leaders and politicians was far from being of the 'right type'. This was especially true of the assisted migrant, most of which were primarily from urban and industrial backgrounds, and preferred to live and work in Canada's bustling cities and towns. Essentially, their immediate contributions were to the tertiary, commercial and industrial sectors of the Canadian economy. Indeed, for thriving metropoles like Toronto, Winnipeg and Vancouver, the British - or more accurately the English character of these cities - were certainly being reinforced by this new intake of neo-Britons from the 'mother country'. In that respect, Britishness was being reinforced, but it was primarily in urban not rural environments.

Compounding this problem was another unmistakable fact. Continental immigration surpassed British intake after 1925-6 and maintained its numerical dominance throughout the rest of the decade. ${ }^{109}$ Yet, here is an interesting paradox. Aggressive marketing by the railway companies had much to do with the increasing number of arrivals from continental Europe, despite that fact that between 1922 and 1935 over 107,000 people from the British Isles were given assistance to migrate to Canada. ${ }^{110}$ This was a far cry from the millions that dreamers like Amery had 
envisioned. Moreover, it was the European immigrants who made a much more significant contribution to the development of Canada's primary resource sector in the 1920s. They were cheaper, more adaptable and possessed the requisite skills and backgrounds necessary for pioneering on the western prairies or working in the forests of northern Canada. Above all, the vast majority were loyal citizens, who were eager to assimilate to a Canadian way of life and adopt the trappings of Britishness. ${ }^{111}$ In the end, arguments over racial purity, ethnicity and the need to augment Canada's AngloSaxon character failed to supplant the fundamental economic reality in 1920s Canada: that it needed skilled migrants irrespective of racial background to develop its expanding hinterland. The simple irony was that after the Great War the increasing majority of migrants involved in this national project were not British. Paradoxically, British government funding of emigration throughout the empire in the 1920s owed more to post-war anxieties about the feared consequences of demobilisation and economic decline in Britain than to imperial sentiment or shoring up Anglo-Canadian cultural values. Financial and political priorities subordinated the lofty cultural aspirations almost every time.

Finally, it was also recognized by London and Ottawa that migration could not be used simply as a bargaining tool in Anglo-Canadian relations or be solely directed to the complementary issues of how to increase dominion productivity, expand markets for dominion produce and safeguard markets for British manufacturing. Imperial migration was a joint venture that required active support and encouragement on both sides of the Atlantic. Co-operation not confrontation was the new watchword. Conversely, the dominions could not have it all their own way. British officials argued that in future assisted settlement schemes the dominions would have to be 
prepared to contribute on an equal share financially. More importantly, the onus was on the dominions to provide better settler support and aftercare. ${ }^{112}$ In the context of Anglo-Canadian relations, the renewal of the Empire Settlement Act in 1938 reflected these changes both in attitude and policy. These transformations were significant for another key reason. The compromises made in the spheres of assisted migration and empire settlement between these two nations demonstrated the reality of the new footing on which Anglo-dominion relations was being established. It demonstrated what dominion-hood meant in practice; how dominion political autonomy, especially in the all-important exercises of nation-building and ethnic construction, could be exercised with due acknowledgement of the imperial connection. Furthermore, it was in this continuing and complex interplay between ethnicity and economics that the British World was restocked and (re)defined. 


\section{REFERENCES}

* The author wishes to thank the Canadian High Commission, London, for a grant in aid of research through its Canadian Studies Faculty Program. Incisive comments on earlier drafts were provided by Professor Andrew Thompson (Exeter University).

${ }^{1}$ Larkin to King, 23 May 1923, William Lyon Mackenzie King papers, reel C-2259, MG 26 J1 series, vol. 95, 75160, Library and Archives Canada (LAC).

${ }^{2}$ Alan Sears, 'Immigration Controls as Social Policy: The Case of Canadian Medical Inspection 19001920', Studies in Political Economy, 33 (1990): p. 103. The emphasis in the quotation is mine. Lorna McLean, "To Become Part of Us": Ethnicity, Race, Literacy and the Canadian Immigration Act of 1919', Canadian Ethnic Studies, 36, no. 2 (2004): pp. 1-28.

${ }^{3}$ Carl Berger, The Sense of Power. Studies in the Ideas of Canadian Imperialism 1867-1914 (Toronto, 1970).

${ }^{4}$ Barbara Roberts, “"A Work of Empire”: Canadian Reformers and British Female Immigration', in $A$ Not Unreasonable Claim: Women and Reform in Canada 1880s-1920s, ed. Linda Kealey (Toronto, 1979), p. 186.

${ }^{5}$ John Darwin, 'A Third British Empire? The Dominion Idea in Imperial Politics', in Oxford History of the British Empire, Volume IV, The Twentieth Century, eds. Judith M. Brown and Wm. Roger Louis (Oxford, 1999), pp. 64-87; id, 'Empire and Ethnicity', Nations and Nationalism, 16, no. 3 (2010): pp. 383-401.

${ }^{6}$ P. G. Wigley, Canada and the Transition to Commonwealth (Cambridge, 1977); R. F. Holland, Britain and the Commonwealth Alliance 1918-1939 (Basingstoke, 1981).

${ }^{7}$ A starting point is Carl Bridge and Kent Fedorowich, eds., The British World: Diaspora, Culture and Identity (London, 2003); Kent Fedorowich and Andrew S. Thompson, eds., Empire, Migration and Identity in the British World (Manchester, 2013).

${ }^{8}$ Ian M. Drummond, Imperial Economic Policy 1917-1939: Studies in Expansion and Protection (London, 1974).

${ }^{9}$ For a select sample see Katie Pickles, Female Imperialism and National Identity (Manchester, 2002); Lisa Chilton, Agents of Empire (Toronto, 2007); Janice Cavell, 'The Imperial Race and the Immigration Sieve: The Canadian Debate on Assisted British Migration and Empire Settlement, 1900-30', Journal of Imperial and Commonwealth History, 34, no. 3 (2006): pp. 345-67; Kurt Korneski, 'Britishness, Canadianness, Class, and Race: Winnipeg and the British World, 1880s-1910s', Journal of Canadian Studies, 41, no. 2 (2007): pp. 161-84; Rebecca Mancuso, 'For Purity or Prosperity: Competing Nationalist Visions and Canadian Immigration Policy, 1919-30', British Journal of Canadian Studies, 23, no. 1 (2010): pp. 1-23.

${ }^{10}$ Robert Bickers, ed., Settlers and Expatriates: Britons over the Seas, companion series, Oxford History of the British Empire (Oxford, 2010); Marjory Harper and Stephen Constantine, Migration and Empire, ibid (Oxford, 2010).

${ }^{11}$ Philip Buckner, ed., Canada and the British Empire, companion series, Oxford History of the British Empire (Oxford, 2008); Deryck M. Schreuder and Stuart Ward, eds., Australia's Empire, ibid (Oxford, 2008). 
12 Joy Parr, Labouring Children (Kingston \& Montreal, 1980); Roy Parker, Uprooted: The Shipment of Poor Children to Canada, 1867-1917 (Bristol, 2008); Patricia T. Rooke and R. L. Schnell, 'Imperial Philanthropy and Colonial Response: British Juvenile Emigration to Canada, 1896-1930', The Historian, 46, no. 1 (1983): pp. 56-67; R. L. Schnell, 'The right class of boys: youth training schemes and assisted emigration to Canada under the Empire Settlement Act, 1922-39', History of Education, 24, no. 1 (1995): pp. 73-90.

${ }^{13}$ David Smith, 'Instilling British Values in the Prairie Provinces', Prairie Forum, 6, no. 2 (1981): pp. 129-41; Marilyn Barber, "“A Religious and Patriotic Way of Earning One's Daily Bread”: Church of England Teachers in Western Canada, 1909-1939', British Journal of Canadian Studies, 16, no. 1 (2003): pp. 26-36.

${ }^{14}$ Marilyn Barber, 'Nation Building in Saskatchewan: Teachers from the British Isles in Saskatchewan Rural Schools in the 1920s', in Canada and the British World: Culture, Migration and Identity, eds. P. Buckner and R. D. Francis (Vancouver, 2006), pp. 215-33.

${ }^{15}$ Mariana Valverde, The Age of Light, Soap \& Water: Moral Reform in English Canada, 1885-1925 (Toronto, 2008), pp. 104-28; Myra Rutherdale, “"Canada is no dumping ground": Public Discourse and Salvation Army Immigrant Women and Children, 1900-1930', Histoire sociale - Social History, 40, no. 79 (2007): pp. 75-115.

${ }^{16}$ Henry Drystek, 'The Simplest Mode of Dealing with Them: Deportation from Canada before World War II', Histoire sociale - Social History, 15, no. 14 (1982): pp. 407-41; Barbara Roberts, Whence They Came: Deportation from Canada 1900-1935 (Ottawa, 1988); Angela McCarthy and Catharine Coleborne, eds., Migration, Ethnicity, and Mental Health: International Perspectives, 1840-2010 (London, 2012).

${ }^{17}$ Robert Boyce, 'Insects and International Relations: Canada, France, and British Agricultural Sanitary Import Restrictions between the Wars', International History Review, 9, no. 1 (1987): pp. 1-27; id, 'Canada and the Pacific Cable Controversy, 1923-28: Forgotten Source of Imperial Alienation', Journal of Imperial and Commonwealth History, 26, no. 1 (1998): pp. 72-92.

${ }^{18}$ King to Charles Stewart, acting minister of immigration and colonization, 15 February 1922, enclosing letter from McCulloch to King, 13 December 1921, King papers, reel C-2250, J1 series, vol. 82, 69291-3, LAC.

19 For more on the anti-alien movement see Donald Avery, 'Dangerous Foreigners'. European Immigrant Workers and Labour Radicalism in Canada, 1896-1932, reprint (Toronto, 1983), pp. 65115, and J. H. Thompson, The Harvests of War. The Prairie West, 1914-1918 (Toronto, 1978).

${ }^{20}$ For a more detailed analysis of these themes see Kent Fedorowich, Unfit for Heroes: Reconstruction and Soldier Settlement in the Empire between the Wars (Manchester, 1995), pp. 70-114.

${ }^{21}$ Tom Mitchell, “"The Manufacture of Souls of Good Quality”: Winnipeg's 1919 National Conference on Canadian Citizenship, English-Canadian Nationalism, and the New Order after the Great War', Journal of Canadian Studies, 31, no. 4 (1996-97): pp. 5-28.

${ }^{22}$ John A. Schultz, 'Finding Homes Fit for Heroes: The Great War and Empire Settlement', Canadian Journal of History, 18, no. 1 (1983): p. 99.

${ }^{23}$ Dane Kennedy, 'Empire Migration in Post-war Reconstruction: the Role of the Overseas Settlement Committee', Albion, 20, no. 3 (1988): pp. 03-19.

${ }^{24}$ Toronto Star, 12 June 1920. 
${ }^{25}$ Kent Fedorowich, 'The assisted emigration of British ex-servicemen to the dominions, 1914-1922', in Emigrants and Empire, ed. Stephen Constantine (Manchester, 1991), pp. 45-71; Lucy Noakes, 'From War Service to Domestic Service: Ex-Servicewomen and the Free Passage Scheme 1919-22', Twentieth Century British History, 22, no. 1 (2011): pp. 1-27.

${ }^{26}$ A. L. Jolliffe, commissioner of immigration, Vancouver, to Blair, 30 January, 3 and 30 August 1920, Department of Immigration and Colonization papers, RG 76, vol. 585, fol. 821430, part 2; Blair to W. W. Cory, deputy minister of the interior, 18 May and 3 July 1920, ibid., part 4, LAC.

${ }^{27}$ Blair to Cory, 18 May 1920, ibid., part 4, LAC.

${ }^{28}$ W. L. Morton, The Progressive Party in Canada, $2^{\text {nd }}$ reprint (Toronto, 1971).

${ }^{29}$ Randy William Widdis, With Scarcely a Ripple. Anglo-Canadian Migration in to the United States and Western Canada, 1880-1920 (Montreal \& Kingston, 1998), xx and pp. 64-5.

30 Jean-Pierre Beaud and Jean-Guy Prévost, 'Immigration, Eugenics and Statistics: Measuring Racial Origins in Canada (1921-1941)', Canadian Ethnic Studies, 28, no. 2 (1996): pp. 1-24; John A. Schultz "'Leaven for the Lump": Canada and Empire settlement, 1918-1939', in Emigrants and Empire, pp. $150-73$.

${ }^{31}$ Memo for O. D. Skelton, under-secretary of state for external affairs, c.1924, King papers, reel C2694, J4 series, vol. 80, file 623, C60952-7, LAC.

${ }^{32}$ Canadian government press release, 11 September 1922, ibid., C60921, LAC.

${ }^{33}$ Black to Larkin, 14 March 1922, Department of External Affairs papers, RG 25, series A-2, vol. 203, I44/67, LAC.

${ }^{34}$ H. Blair Neatby, William Lyon Mackenzie King, Volume II, 1924-32: The Lonely Heights (Toronto, 1963), pp. 99-100.

${ }^{35}$ PC 330, 10 February 1922, RG 76, vol. 259, fol. 201936, LAC; King to Larkin, 2 February 1922, King papers, reel C-2246, J1 series, vol. 78, 64256-7, LAC; Larkin to King, 30 June 1922, ibid., 64399-401; Larkin to Stewart, 13 November 1922, ibid., 64691-3, LAC; Larkin to King, 15 November 1922, ibid., 64694-7, LAC; memo by Reid Hyde, 30 November 1922, reel C-2266, J1 series, vol. 103, 87016-36, LAC; Black to Larkin, 14 March 1922, RG 25, series A-2, vol. 203, I44/67, LAC; Stewart to Larkin, 2 December 1922, ibid., I44/68, LAC. See Roy MacLaren, Commissions High: Canada in London, 1870-1971 (Montreal \& Kingston, 2006), pp. 223-69, for Larkin's tenure as high commissioner.

${ }^{36}$ Obed Smith to J. W. Dafoe, 10 November 1924, J. W. Dafoe papers, MG 30, D45, reel M-74, LAC.

${ }^{37}$ Undated memo for 1923 Imperial Economic Conference (October-November 1923), King papers, reels C-2259 and C-2260, J1 series, vol. 95, 80720-3, LAC.

${ }^{38}$ Larkin to King, 24 May 1923, RG 25, series A-2, vol. 297, P/10/38, LAC.

${ }^{39}$ King to Larkin, 12 May 1923, ibid.

${ }^{40}$ King to Larkin, 10 July 1923, ibid; Larkin to King, 1 December 1923, King papers, reel C-2255, J1 series, vol. $89,75425-9$, LAC.

${ }^{41}$ John A. Schultz, 'Canadian Attitudes toward Empire Settlement, 1919-1930', Journal of Imperial 
and Commonwealth History, 1, no. 2 (1973): p. 242.

${ }^{42}$ Philip Williamson and Edward Baldwin, eds., Baldwin Papers: A Conservative Statesman, 19081947 (Cambridge, 2004), p. 112.

${ }^{43}$ Pacaud to McGregor, 7 February 1924, King papers, reel C-2266, J1 series, vol. 102, 86755-6, LAC.

${ }^{44}$ Blair to Skelton, 18 September 1923, O. D. Skelton papers, MG 30, D33, vol. 42, file 4, LAC.

${ }^{45}$ Report by Captain T. B. Trappes-Lomax, department of military operations, on a visit to Canada sponsored by the war office (October-November 1925), Dominions Office papers, DO 35/17, The National Archives (Kew).

${ }^{46}$ Diary entries, 14 May 1925 and 23 May 1927, Leo Amery papers, AMEL 7/19 and AMEL 7/21, Churchill Archive Centre, Cambridge (CAC). Many western delegates attending the 1927 Anglican Synod of Canada held in Toronto launched a scathing attack on federal immigration policy accusing Ottawa of threatening to shatter the British connection by its sanctioning of this great influx of foreign born. Rev. P. J. Andrews, secretary of the Fellowship of the Maple Leaf, to Plant, 21 October 1927, enclosing editorials from the Toronto Globe and the Toronto Mail and Empire, September - October 1927, copies of which were also sent to the Bishop of London by Andrews, DO 57/50/6624, TNA; Larkin to King, 23 September 1927 and King’s reply, 24 September 1927, King papers, reel C-2298, J1 series, vol. 145, 123076-7 and 123078-82, LAC.

${ }^{47}$ Stanley to the Reverend M. A. Haig, Archbishop of Canterbury's private secretary, April 1926, vol. 327, fol. 44; and Stanley to Haig, 22 September 1926, fols. 84-6, Lambeth Palace Library, Lord Davidson of Lambeth papers. Davidson was the Archbishop of Canterbury from 1903 to 1930.

${ }^{48}$ Avery, 'Dangerous Foreigners', pp. 100-12; Ninette Kelley and Michael Trebilcock, The Making of the Mosaic. A History of Canadian Immigration Policy (Toronto, 1998), pp. 209-11; John Herd Thompson with Allen Seager, Canada 1922-1939: Decades of Discord (Toronto, 1985), pp. 130-1. The easing of the restrictions in favour of the railway and shipping tycoons also concerned female civil servants newly hired by Ottawa in the department of immigration and colonization which, in 1920, established a women's division. Mancuso, 'Purity or Prosperity'; id, 'Work "Only a Woman Can Do": The Women's Division of the Canadian Department of Immigration and Colonization, 1920-1937', American Review of Canadian Studies, 35, no. 4 (2005): pp. 593-620.

${ }^{49}$ Gardiner to King, 23 August 1927, King papers, reel C-2296, J1 series, vol. 143, 121723-7, LAC; King to Larkin, 24 September 1927, reel C-2298, J1 series, vol. 145, 123078-82, LAC; Dafoe to H. Napier Moore, editor of MacLean's Magazine, 15 October 1928, Dafoe papers, reel M-75, LAC. Also see Robert A. Wardhaugh, Mackenzie King and the Prairie West (Toronto, 2000), pp. 115-6, where he examines the competing agendas on immigration between eastern and western Canada.

${ }^{50}$ Willingdon to Amery, 25 May 1927, AMEL 2/4/5, CAC.

${ }^{51}$ Willingdon to Amery, 28 July 1928, ibid.

${ }^{52}$ Willingdon to Amery, 25 May 1927, ibid.

${ }^{53}$ Minutes by W. Garnett, assistant principal, and Plant, Overseas Settlement Department (OSD), 17 March and 26 April 1927, DO 57/37/1202, TNA.

${ }^{54}$ Barnett to Macnaghten, 31 December 1926, DO 57/9/7851, TNA.

${ }^{55}$ Obed Smith to Dafoe, 10 November 1924 and Walker to Dafoe, 29 June 1926, Dafoe papers, reel M- 
74, LAC. Larkin's views can be found in a letter to King, 31 December 1925, King papers, reel C2278, J1 series, vol. 117, 99957-99964A, LAC.

${ }^{56}$ Forke to Dafoe, 27 October 1927, Dafoe papers, reel M-74, LAC.

${ }^{57}$ E. T. Crutchley, finance officer, OSD, to Macnaghten, 22 November 1927, DO 57/46/2693, TNA.

${ }^{58}$ Amery to Byng, 30 January 1925, AMEL 2/4/4, CAC. For an intriguing analysis of this scheme see Rebecca Mancuso, 'Three Thousand Families: English Canada's Colonizing Vision and British Family Settlement 1919-39', Journal of Canadian Studies, 45, no. 3 (2011): pp. 5-33.

${ }^{59}$ Diary entry, 26 March 1926, AMEL 7/20, CAC.

${ }^{60}$ Pagé to Amyot, 27 December 1919, Department of Health papers, RG 29, vol. 287, file 402-3-2, LAC.

${ }^{61}$ John Barnes and David Nicholson, eds., The Leo Amery Diaries, Volume I, 1896-1929 (London, 1980), p. 567; diary entry, 25 March 1926, AMEL 7/20, CAC.

${ }^{62}$ Diary entry, 16 April 1926, AMEL 7/20, CAC.

${ }^{63}$ Diary entry, 25 October 1926, AMEL 7/20, CAC.

${ }^{64}$ Diary entry, 18 June 1926, ibid.

${ }^{65}$ Macnaghten to William Bankes Amery, finance officer, OSD, 5 February 1926, DO 57/14/648, TNA; Macnaghten to Bankes Amery, 28 July 1927, DO 190/2, TNA.

${ }^{66}$ Dominions office circular entitled, 'State-Aided Empire Migration and Settlement', January 1926, DO 57/13/1831, TNA.

${ }^{67}$ Notes of Ottawa conference held on 27-28 September 1926, DO 57/7/6409, TNA.

${ }^{68}$ Clarendon to Blair, 5 December 1926, Records of the Public Service Commission, RG 32, C-2, vol. 420, second file on F. C. Blair, LAC.

69 'The Present Position of Imperial Migration under the Empire Settlement Act', memo by Sir Arthur Steel-Maitland, minister of labour, to Amery, August 1926, DO 57/13/4715, TNA.

${ }^{70}$ Memo by Wilfrid Eady, assistant secretary, ministry of labour, July 1926, DO 57/13/4064, TNA.

${ }^{71}$ Steel-Maitland to Amery, August 1926, DO 57/13/4715, TNA.

${ }^{72}$ Memo by Eady, July 1926, DO 57/13/4064, TNA.

${ }^{73}$ Free Press Evening Bulletin, 28 May 1927.

${ }^{74}$ Amery to Buchan, 21 May 1927, John Buchan papers, box 5, Queen's University Archives (Kingston, ON).

${ }^{75}$ Barnes and Nicholson, eds., Amery Diaries, Volume I, p. 29.

${ }^{76}$ Amery to King George V, 9 February 1928, AMEL 2/1/16, CAC. For Amery's conversations with Mackenzie King while in Canada see memo entitled 'Short notes', c.1928, DO 117/93, TNA. 
${ }^{77}$ Amery to King George V, 9 February 1928, AMEL 2/1/16, CAC.

${ }^{78}$ The Times, 24 January 1928.

${ }^{79}$ Ibid.

${ }^{80}$ Western Daily Press (Bristol), 25 January 1928.

${ }^{81}$ Morning Post, 20 April 1928.

${ }^{82}$ Greenock Telegraph, 4 February 1928. Also see the North Mail (Newcastle), Daily Dispatch (Manchester), and the Glasgow Record and Mail, all dated 3 February 1928.

${ }^{83}$ Shipping World, 22 February 1928; Glasgow Evening News, 18 February 1928.

${ }^{84}$ Confidential memo, Noxon to King, 21 May 1928, King papers, reel C-2694, J4 series, vol. 80, file 625, C61055-8, LAC.

${ }^{85}$ Dr D. A. Clark, assistant deputy minister, department of health, to Egan, 5 June 1926; and Clark memo for the minister of health, supplementary estimates for 1927, n.d., LAC, RG 76, vol. 348, fol. 376333, part 2, LAC.

${ }^{86}$ Jolliffe to Egan, 12 April 1928, ibid., part 5, LAC.

${ }^{87}$ Notes of a conference on immigration held in Egan's office, 17, 18 and 20 August 1928 (21 August 1928), RG 76, vol. 330, fol. 329091, LAC. For Lovat's proposed land settlement scheme and the lack of Canadian enthusiasm, especially over the vague financial provisions, see memo in King papers and Lovat to Forke, 3 September 1928, King papers, reel C-2694, J4 series, vol. 80, file 625, C61063-7 and C61068-9, LAC; Forke to King, 30 October 1928, King papers, reel C-2303, J1 series, vol. 152, 129583, LAC; Dafoe to Sifton, 28 September 1928, and Sifton to Dafoe, 5 October 1928, Dafoe papers, reel M-75, LAC. For Lovat's frustrating experiences in Canada while on tour see Lovat to Amery, 19 September 1928, marked 'For our Secret use', DO 57/90/1001, TNA.

${ }^{88}$ The Times, 11 August 1928; Marjory Harper, Emigration from Scotland between the Wars: Opportunity or Exile? (Manchester, 1998), pp. 101-06.

${ }^{89}$ W. J. C. Cherwinski, “Misfits", "Malingerers", and "Malcontents": The British Harvester Movement of 1928', in The Developing West, ed. John E. Foster (Edmonton, 1983), pp. 71-302.

${ }^{90}$ Diary entries for 16, 18, 21 and 25 October 1928, E. T. Crutchley diaries (microfilm), M1829, reel 1, National Library of Australia, Canberra.

${ }^{91}$ Note of conversation between Egan and Clark, 10 July 1929, DO 57/99/5752, TNA.

${ }^{92}$ Roberts, Whence They Came, 38; Avery, 'Dangerous Foreigners', p. 197; Canada, Annual Report ${ }_{2}$ 1929-30, Volume II, Department of Immigration and Colonization, table xlvi, p. 55.

${ }^{93}$ Draft notes by Plant, 15 August 1928 and 11 January 1929, DO 57/69/0984/1, TNA.

${ }^{94}$ Neatby, Lonely Heights, p. 241.

${ }^{95}$ Drummond, Imperial Economic Policy, pp. 100-4; memos of discussion with Clark, 15 and 17 November 1928, King papers, reel C-2694, J4 series, vol. 80, file 625, C61079-85 and C61094-99, LAC. 
${ }^{96}$ Minute by Sir E. J. Harding, assistant under-secretary of state for dominion affairs, 19 October 1928, DO 57/66/8094, TNA; minute by Macnaghten, 5 April 1928, DO 57/112/0258, TNA.

${ }^{97}$ Skevington to A. P. Waterfield, assistant secretary, treasury, 10 April 1929, Treasury papers, T $161 / 228$, S 23424/01/2, TNA. Skevington's fascinating insights of his tour to Canada, New Zealand and Australia between July 1928 and February 1929 appears in T 161/706/S 34376.

${ }^{98}$ Thomas to Ponsonby, 24 June 1929, DO 57/105/4994, TNA.

${ }^{99}$ Ponsonby to Thomas, 21 June 1929, Board of Trade papers, BT 56/45/CIA/1958, TNA; Parliamentary Debates, Commons, $5^{\text {th }}$ ser., vol. 229 (1929-30), col. 106; Skevington's report on his visit to Canada with Lovat, April 1929, and minute by Macnaghten, 5 April 1929, DO 57/112/0258, TNA.

${ }^{100}$ Lansbury to MacDonald, 9 May 1930, enclosing a memo he had sent to Thomas in July 1929, J. Ramsay MacDonald papers, PRO 30/69/340, TNA. This was reiterated in Parliamentary Debates, Commons, 5th ser., vol. 240 (1929-30), col. 1401.

${ }^{101}$ Schultz, “'Leaven for the Lump”', p. 168; Kelley and Trebilcock, Mosaic, pp. 215-16; King to Forke, 1 August 1929, and Forke to Thomas, 23 August 1929, King papers, reel C-2309, J1 series, vol. 161, 137545 and 137550-1, LAC; Egan to Stewart, 11 January 1930, reel C-2317, J1 series, vol. 173, 147805, LAC; Skelton to King, 16 August 1929, reel C-2475A, J4 series, vol. 51, C40985, LAC.

${ }^{102}$ H. F. Carlill, assistant secretary, board of trade, to Evelyn Wood, under-secretary of state for the colonies, 30 September 1921, Colonial Office papers, CO 532/190/59099, TNA; summary of correspondence concerning Amery memos presented to cabinet, CP 3582 and CP 3582A, 28 November 1921, BT 65/11/PTE 2981, TNA.

${ }^{103}$ Lothian to Lovat, 9 July 1928, Lord Lothian papers, GD 40/17/242, fol. 476, National Archives of Scotland, Edinburgh.

${ }^{104}$ Joynson-Hicks to Baldwin, 31 January 1929, Stanley Baldwin papers, vol. 12, Cambridge University Library.

${ }^{105}$ Minutes of the $268^{\text {th }}$ meeting of the OSC, 4 July 1929, TNA, DO 57/104/5242, TNA; Clark to Amery, 10 January 1929, Ministry of Labour papers, LAB 2/1235/EDO 220, TNA.

${ }^{106}$ Report by Crutchley entitled, 'Migration to Australia' (1932), 2, T 161/531/S 34376/02, TNA.

${ }^{107}$ Memo on immigration policy submitted to King's office by Egan, 17 May 1929, King papers, reel C-2309, J1 series, vol. 161, 137280-95, LAC.

${ }^{108}$ Eady to P. Liesching, principal secretary, dominions office, 11 March 1929, LAB 2/1235/EDO 220, TNA; Amery memo for Baldwin, 'Unemployment and Migration', 24 July 1928, DO 57/72/5747, TNA. Also see David Goutor, Guarding the Gates: The Canadian Labour Movement and Immigration, 1872-1934 (Vancouver, 2007), for the tensions between Canadian labor and British migration.

${ }^{109}$ Canada, Annual Report, 1929-30, Volume II, table v, p. 12.

${ }^{110}$ Schultz, “'Leaven for the Lump”,' p. 168.

${ }^{111}$ Donal Lowry, 'The Crown, Empire Loyalism and the Assimilation of Non-British White Subjects in the British World: An Argument against "Ethnic Determinism"', in British World, pp. 96-120. 
112 House of Commons Parliamentary Papers, Cmd. 4689, Report to the Secretary of State for Dominion Affairs of the Inter-Departmental Committee on Migration Policy (1934), p. 22; Cmd. 5766, Report of the Oversea Settlement Board, May (1938), pp. 16-19 and 36. 